\title{
RELIGIOUS INTOLERANCE: THE MAXIMUM DENIAL OF ALTERITY
}

\author{
EDNA RAQUEL HOGEMANN ${ }^{1}$ \\ SERGIO LUIS TAVARES
}

\begin{abstract}
It analyses aspects of religious intolerance in Brazil, its cause-and-effect relationship with radical proselytism, negative consequences for the exercise of the right to religious freedom and other human rights, some manifestations in the Brazilian multireligious scenario, some potentially effective instruments for prevention intolerance, among which are the practices of alterity. It shows that Brazil, does not present a chaotic picture in terms of intolerance, but has worrying records of persecution, discrimination and acts of violence, for religious reasons, which should serve as a warning for implementation of affirmative actions and public policies regarding the duty of respect and solidarity with others.
\end{abstract}

Keywords: human rights; religion; religious freedom; afro-brazilian religious intolerance; alterity

Summary: 1. Introduction. 2. Religiosity and the Dangers of Religious Intolerance. 3. Religious Intolerance as a Sequel to Unbridled Proselytism. 4. Religious Intolerance in the Brazilian Multireligious Mosaic. 5. Some Instruments for Reducing Religious Intolerance. 6. Concluding Remarks

\section{INTRODUCTION}

There are many challenges to achieving reasonable levels of consensus and peaceful coexistence among human beings. As well as the lack of dialogue on more objective issues that pervade social life, there are deadlocks, controversies, and disputes, what can be said about clashes between diverse convictions and beliefs, often antagonistic about certain dogmas, principles, and customs.

This scenario is further aggravated by the fact that the same human right to freedom of religion of a given individual is used by him as a weapon against the identical right of the other and, in this conflict, one or both parties maintain that they hold the absolute truth with them.

From this perspective of misrepresentation, what would be a human right, and fundamental in many national legal systems, is now interpreted and used as a free pass for abusive conduct of prejudice, persecution, violence and other forms of offences against other individuals or groups.

Religious intolerance stems from the mismanaged confrontation of distinct cultures and religious traditions, which refers to the concept of interculturality, and is a phenomenon witnessed by humanity in practically every age and part of the world.

${ }^{1}$ UFRJ and Permanent Professor of the Graduate Program in Law and Dean, at the Federal University of the State of Rio de Janeiro - UniRio, Brazil (ershogemann@gmail.com). 
Religion, as a social phenomenon, lacks the minimum standards for coexistence among individuals and between individuals and the state, so that acts of religious intolerance are avoided or, if not, repressed.

Religious freedom, being a right with many faces and which, in essence, requires no state interference, and considering its high subjective load, is potentially fertile ground for the occurrence of abuses in the name of this same right, such as hateful and intransigent behavior and discourses directed to those who do not declare themselves believers or who are believers of other religions.

The first part of this essay discusses religiosity and the dangers of religious intolerance. However, in the name of that belief (or not belief), the individual is not allowed, morally and legally, to be intolerant with the other who believes (or does not believe), according to his expectations or his worldview.

In the second part, the essay discusses religious intolerance as an effect of disproportionate, unreasonable, unbridled religious proselytizing, inciting aggression, discrimination, and prejudice, which constitutes a deformity of religious freedom, since it transforms the defense of faith (religious proselytizing and apology for belief) into a weapon of attack (fundamentalism, sectarianism, religious intolerance).

The following part is dedicated to discussing the hypotheses and episodes of religious intolerance, especially in the Brazilian scenario, both on the basis of statistical and journalistic data, and under a structure of theological, anthropological and sociological reflections.

The last section of this study suggests some instruments for combating religious intolerance, such as international documents that stipulate this commitment, teachings of the religions themselves, specific and effective public policies for this purpose, as well as proposals for the constant stimulation of interreligious dialogue and the practices of otherness.

Fighting religious intolerance in Brazil, as in any part of the world, is above all a posture of a political and juridical need, to be assumed by all, in order to avoid bitter fruits being harvested ahead and holy wars being hypocritically fought by achieving a supposed but false peace.

\section{Religiosity and the Dangers of Religious Intolerance}

It would not be expected that everyone would experience in the same way the experience that each one goes through in his or her action of reconnecting (-seeing) with some being or with something superior and transcendent, capable of leading it originally or returning it to a level of security, peace, hope or other pleasant feelings or emotions.

In more precise terms, the way of transcending is personal, so one cannot necessarily demand that someone understand, except through empathy and otherness, the faith and 
any other form of conviction of another human being, even if he or she becomes part of the same community of believers.

Considering that, even within the same religious group, devotion takes place through an essentially individual profession of faith, and therefore diversity is present, what about individuals and groups who have distinct views and separate perceptions of the world?

This pluralism of beliefs and non-beliefs also radiates through its immersion in other environmental and social vectors related to the history of each society, customs, traditions, languages, schooling levels, climate conditions, levels of economic development, and many other factors.

In terms of the exercise of faith, living together and respecting diversity and pluralism should be something umbilically related to the right to religious freedom itself. But reality always seems to be very different. It is important to consider Winnifred (2014) words:

You cannot both celebrate religious freedom and deny it to those whose religion you don't like. Human history supports the idea that religion, small " $\mathrm{r}$ " religion, is a nearly ubiquitous and perhaps necessary part of human culture. Big "R" Religion, on the other hand, the Religion that is protected in constitutions and human rights law under liberal political theory, is not. Big " $R$ " Religion is a modern invention, an invention designed to separate good religion from bad religion, orthodoxy from heresy-an invention whose legal and political use has arguably reached the end of its useful life

Therefore, when we talk about a constitutionally guaranteed freedom of religion, it is difficult to explain why only one or another religion is effectively protected and normally these guarantees are only given to the religion of white people here in our country. Nevertheless, the conduct of intolerance hovers dangerously over any field of social coexistence, forming itself by the absurd certainty of the possession of an absolute truth, which can evolve into the construction of a thought of imposing this truth on others. When it comes to religious performance, these risks seem to be even greater and more complex.

As a historical landmark, John Locke, through his work Letter About Tolerance (of 1689), showed himself to be an advocate of religious tolerance. Paradoxically, Locke listed cases in which intolerance against Catholics and atheists was necessary (LOCKE, 1978).

In this sense, it is important to point out that Locke understood individual freedom as a civil good. It was up to the government to preserve this inalienable asset. The existence of freedom was combined with presence and tolerance. Just because, if different individuals, with different perceptions and worldviews (albeit with the same cultural base), are free in their consciousness, in their thinking, they become responsible for preserving the freedom 
of others. And the freedom of the other can only exist if there is tolerance. The purpose of freedom for Locke was to better fulfill moral duties (MICHAUD, 1991, p.66).

The English philosopher, therefore, defended an ideal of tolerance simultaneously ethical and political, with a sensible predominance of lay arguments over theological ones.

It advocates the abolition of civil and religious privileges for the construction of a peaceful society, proposing the necessary separation between religious and civil powers which, if interfered with, hinder the free exercise of religious conscience. Notwithstanding the advance of these conceptions, it should be noted that the author excluded from his concept of tolerance atheists and Catholics, considering them dangerous to the balance and strengthening the state (MICHAUD, 1991, p.71).

For the author, intolerance of Catholics was due to the idea that they would represent a threat to the kingdom since they would be subjects of a foreign sovereign and of a power considered superior to any other. As for the intransigence related to atheists, he was on the assumption that the lack of a religious belief would make a stable normative reference among men impossible.

The spectrum of religious intolerance also goes the way of denying the religion of the other, for example, on the grounds that it is a sect, something demonic, or mere philosophy.

From this reasoning, only the opinion, shared by many, regarding the difficulty in conceptualizing what religion is, is taken advantage of, since the word carries a variety of meanings, but one can risk affirming that religion consists of a system of ideas, beliefs and organized practices, capable of influencing an individual or a collectivity, in the search to associate the human element with the divine, sacred, eternal element.

Considering that religiosity harbors conceptual difficulties and diversity as to worldview, derives from the confluence of numerous chronological and geographical vectors, and is legally embodied in the idea of the freedom of its exercise, it remains to be seen that the emphasis on the transcendent and the immanent has made known the dichotomy, which here is preferred to call sacralization versus desacralization, although it would be sufficient simply to analyze the comings and goings in the historical processes of secularization of societies.

Zanone (1986, p. 673) states that the term secularization in sociological literature is normally used to characterize the process of transition from patriarchal, rural and closed societies to industrialized, urban and unholy society, where there is a constant reduction in the social weight of organized religion.

It is true that secularization is also noted for the prospect of the individual taking possession of his or her freedom of conscience in order to assume and declare himself or herself, for example, to be an atheist or agnostic and to demonstrate this by breaking with the practices and customs dictated by religion, such as ignoring the meaning of Christmas 
or Easter or despising the possible benefits of a prayer, a cult or any other manifestations of faith.

Although the concept of secularization usually leads us to an idea of the desacralization of society, it is interesting to note that secularization can produce fruits other than the cooling down of religiosity.

In that sense, Ribeiro says:

It is necessary to emphasize that the process of secularization experienced and halfway through modernity has not produced, as expected, the disappearance or attenuation of religious experiences. On the contrary, in the Christian field, for example, Pentecostal and charismatic forms have gained popular attachment, social space and institutional base in both the evangelical and the Catholic world. Other religions in Brazil and in the world are also experiencing times of reforestation (RIBEIRO, 2014, p. 31).

Thus, as much as secularization may denote man's immanent detachment from the transcendent divinity, observable even in this scenario, the emergence of new religions, understood here not only as other doctrinal trunks, but also as denominations derived from the same religious tradition, originating as dissidents or as simple ramifications of the mother church, constituting, as a rule, syncretic religious movements.

In this sense, it is worth registering the words of Montero (2017):

It therefore appears to us that, more than a political ideology to be adopted or criticized, the phenomenon of secularism can be understood as the result of a disciplinary practice, as outlined by Talal Asad (2003), in which agents learn and acknowledge practices of public justification as a suitable form of recognizing their rights in a world in which no substantive body of beliefs is still able to regulate the totality of collective life on its own (Binoche 2012). In this perspective, in which the plurality of points of view comes to be the condition of all social existence, the political practice of tolerance becomes progressively the most acceptable normative reference as a regulatory principle of the conviviality of differences.

However, it should be emphasized that tolerance as a principle brings with it much controversy.

Montero (2017) separates the current concept from the traditional, by saying that "the current meaning attributed to the idea of tolerance is quite distinct from its historical definition. The emergence of the concept is related to religious disputes about truth (or of the true religion) and of the possibilities for a practical compatibility between distinct faiths". On the other hand, to hold that religious intolerance must be fought legally also implies the social behavior of respect for the devotional style of an individual or collectivity who have decided to assume and express some form of religious belief, provided that it 
does not go beyond what is agreed by law and that it does not outrage similar decisions of other people.

It is important to note that religious prejudice can be present in attempts to ridicule the modus vivendi of those who have decided to confess their faith, whether it belongs to the dominant religious tradition of their society, or even minority in its representation.

As serious as not tolerating the religion of the other is to have to deny their religiosity to fit in with the expectations of social groups that are envious of seeing themselves as desacralized, when it would be enough for them to behave in a secularized way, as much as enough to guarantee harmonious and respectful coexistence among religious collectivities and other institutions occupying the same social space.

Despite the complexity of the discussion, in general terms, the preservation of religious practice, without undue interference from the public authorities and other sectors of society, seems to be far from the reality. The whole point of having a state-protected "right to religious freedom" is that religions tend to not co-exist in harmony without state intervention.

As serious as not tolerating the religion of the other is to have to deny their religiosity in order to fit in with the expectations of social groups that are envious of seeing themselves as desacralized, when it would be enough for them to behave in a secularized way, as much as enough to guarantee harmonious and respectful coexistence among religious collectivities and other institutions occupying the same social space.

\section{Religious Intolerance as a Sequel to Unbridled Proselytism}

The maxim that religion is not discussed deserves to be re-examined in the context of a democratic state, so to bring such jargon to literal rigorism would necessarily be to state, for example, that the public authorities could not prevent excesses practiced in the name of faith, or even that religious people could not express their religious proselytism, which is tantamount to inhibiting the effectiveness of the right to religious freedom.

The word proselytism has its origin in the Greek verb proserchesthai, which means to approximate, evolving to the idea of the purposeful effort to make converts to some religious faith, or to any other kind of idea or thought (CHAMPLIN, v.5, 2008b, p. 470).

It is important to clarify that proselytism has a face that reveals itself as a legitimate and simultaneous manifestation of the fundamental rights to religious freedom and freedom of expression, configuring a modality of freedom of religious expression, which should be, in principle, recognized as a right recognized in the democratic societies.

The breadth of the right to religious freedom reaches the possibility of externalizing such a belief, that is, the self-determination as to expressing, before other individuals, one's own thoughts, sensations, emotions, and perceptions generated in the subjectivity of each religious adept, even as an attempt to convincing other people about those principles and values, reputed as worthy and of great existential value. 
In this sense, it is fully possible to approach the following circumstances: a Protestant who emphasizes the biblical text, a Catholic who reveres the figure of Mary, mother of Jesus Christ, or a Candomblé religious who demonstrates zeal in fulfilling the precepts of his Orixás, consist of legitimate manifestations carried out by the members of these religions, in accordance with their respective precepts, which, due to their simplicity, can even gather proselytes for their respective beliefs - it being certain that it is not in the nature of Afro-Brazilian matrix religions to practice proselytism.

The problem arises when, in the initiative of convincing, or converting someone to his or her creed, mechanisms, strategies or subterfuge are used which decontextualize, demean, or offend the belief (or non-belief) of others, probably the result of excesses or abuses to the genuine freedom of religion until then.

This deformation to the expected contours of religious proselytism occurs through conduct such as the externalization of discourses steeped in segregation, hatred, discrimination, offenses, or even evil satires directed at symbols, deities, holy books, or ecclesiastical leaders of other beliefs and matrices.

Here, it should be clarified that the understanding of religion cannot be based solely on individual belief and, in this sense, religious intolerance does not become a matter of personal inability to accept or understand the faith of the other, that is, not just an interpersonal thing.

It is observable, at least in Brazilian history, that religious intolerance is intertwined with racist conduct and other forms of violence, discrimination, and prejudice, directed at certain individuals and groups, not only because of devotional differences, but also because of differences in ethnicity, gender, economic power and other social factors.

Regarding this intertwining of religious prejudice and other forms of discrimination, including racial discrimination, Mbembe makes it clear that to practice discrimination more easily, while at the same time making it something conceptually unthinkable, "culture" and "religion" are mobilized to take the place of "biology" (Mbembe, 2018, pp. 21-22).

In this sense, and by way of illustration, discrimination, and other attacks on African religiosity at the time of Brazilian colonization (resistant thanks to the syncretic practices that mixed elements of the Roman Catholic faith with the beliefs developed by the black slaves in Brazil), radiate to this day against the heirs of Afro-Brazilian religions.

The sin which has fallen on African religiosity, as having been the profession of faith of enslaved women and men in Brazil, persists today on considerable discriminated layers of Brazilian society, followers of Candomblé, Umbanda, Omolokô and other strands, because these have been the religions of blacks and poor.

Babalawo Santos ${ }^{2}$ (2019) explains that in Brazil, especially nowadays, this mixture of intolerance and prejudice is not only manifested in the depredations of temples

\footnotetext{
${ }^{2}$ Priest in Yoruba worship.
} 
or "terreiros". "It is possible to map these behaviors in the work environment, in the neighborhood and, of course, at school, where only festivals, holidays and content related to Catholicism are celebrated and taught." "People find it very normal to know everything about Greek mythology, and absolutely nothing about the orishas."

This is the reason why it is possible to state that, by definition, religious intolerance can be considered as the act of discriminating against practitioners of historically marginalized religions. In Brazil, for example, the numbers reveal that although only $2 \%$ of the population declares themselves to be practitioners of African-based religions, according to a survey conducted by the Datafolha Institute, released in January 2020, in the first half of 2019, 59\% of allegations of religious discrimination received by the "Dial $100 " 3$ service were from Umbanda, Candomblé and other Afro-Brazilian denominations (numbers released by the Ministry of Women, Family and Human Rights, in 2019).

Considering that the separation between the just exercise of religious freedom, which includes proselyting discourse, and abusive and fundamentalist conduct ends up being the form of expression of one's own convictions and beliefs, one can see how essential it is to weigh the right to religious freedom against the very guarantee of free expression, since both are closely related.

This was observed in an important decision of the Brazilian Federal Supreme Court (STF), which judged Habeas Corpus No. 82.424-2, in which the editor Siegfried Ellwanger Castan was accused of a crime of racism for having, as a writer and partner of the company Revision Editora Ltda., edited, distributed and sold to the public anti-Semitic works of its authorship and of national and foreign authors who, according to the complaint, "address and sustain anti-Semitic, racist and discriminatory messages", intending with, that to "incite and induce racial discrimination, sowing in its readers feelings of hatred, contempt and prejudice against people of Jewish origin" in which, among the arguments, considerations were presented on the moral and legal limits to the exercise of freedom of expression, which fits also as a rule for equitable religious proselytism.

This is what the STF said:

[...] Brazil's adherence to multilateral treaties and agreements, which vigorously repudiate any racial discrimination, including the distinctions between men for restrictions or preferences deriving from race, color, creed, descent, or national or ethnic origin, inspired by the supposed superiority of one people over another, of which are examples of xenophobia, "blacrophobia", "Islamophobia" and anti-Semitism. Freedom of expression. Constitutional guarantee that is not absolute. Moral and legal limits. The right to free expression cannot include, in its scope, manifestations of immoral content [...] Public freedoms are not unconditional, and must

\footnotetext{
${ }^{3}$ Dial 100 or Dial Human Rights is a 24-hour Brazilian service channel that receives phone calls, analyzes and forwards allegations of human rights violations to those responsible.
} 
therefore be exercised in a harmonious manner, observing the limits defined in the Federal Constitution itself [...] The fundamental precept of freedom of expression does not consecrate "the right to incite racism", since an individual right cannot constitute a safeguard for illicit conduct, as is the case with crimes against honor. Prevalence of the principles of human dignity and legal equality. There is a close link between the indispensable, this juridical time which is dragging on without an end, and memory, the appeal of the past to the disposition of the living, the triumph of remembrance over forgetfulness [...] (emphasis added) (BRAZIL, STF, HC 82.424/RS, 2003).

Unbridled proselytism is, conceptually, the denial of one's right to religious freedom, not an expression of it. The accusation that the other, not partaking of a particular religiosity, is doomed to perdition, curse, hell or any kind of eternal or spiritual condemnation cannot justify the same other being assaulted, discriminated against, invaded in his subjectivity, threatened, persecuted, banned or having any of his human rights affected.

In the history of American colonization by Spaniards and Portuguese, the salvific mentality commanded proselytizing discourses and energetic actions of domination against native indigenous populations, which included the degradation of their religiosity, interpreted as rudimentary and heretical.

Dussel explains this process:

The whole imaginary "world" of the indigenous was "demonic" and as such should be destroyed. This world of the Other was interpreted as the negative, pagan, satanic and intrinsically perverse. The method of the tabula rasa was the coherent result, the conclusion of an argument: since the indigenous religion is demonic, and the divine European religion, the former should be totally denied and, simply, religious teaching should begin again and radically from the latter (DUSSEL, 1993, p. 60).

Demonizing the religion of the other seems to have been a constant strategy to constrain, dominate or even destroy undesirable individuals and groups. The holy wars that illustrate the bloodiest pages of mankind well demonstrate this. In many of them, a more detailed analysis will expose that the religious issue served only to justify other levels of disputes.

However, the complete destruction of the other may not be convenient, such that it would be to keep him under some ideological control, even under the farce of a consent to his religious exercise in a clandestine manner.

Analyzing the Brazilian Afro-Catholic syncretism, which has its origins in the senzalas and other hidden corners of the properties of the agricultural producers of our country's colonial era, known as the lords of ingenuity, tolerating the enslaved Negro to exercise his faith, even if syncretized with Catholicism, would not affect the economic interests of that society. 
There is no doubt that the African-based religious cultures in Brazil are a result of the encounter of the African cultural unity described by Diop (2014) and, in the words of Slenes (1992), discovered by enslaved Africans in Brazilian lands. However, as a consequence of the racist structure in which this country was structured, the dialogue between African cultures was singularized by eugenics, which resulted in what Nascimento (2016) pointed out as a folklorization of black culture in Brazil, raised to the condition of exoticism that aroused the interest and even the fascination of the colonizing white, but unable to compose a structure strong enough to break with the racism in which our society is founded (or sunk).

It is interesting to note that, although Catholic priests at the time were responsible for maintaining the moral and religious health of the slave population, according to the provisions of the Council of Trent (1545-1563), what is observed is that religious proselytism has slackened, thanks to the strategy of syncretism adopted by the slaves. From the most historically remote episodes to the present day, in Brazil and in other parts of the world, the stiffening of religious discourse to levels capable of oppressing that which is different in beliefs and convictions tends to consolidate a negative proselytism, which in itself builds delicate scenarios of religious intolerance.

\section{Religious Intolerance in the Brazilian MultiReligious Mosaic}

In essence, Brazilian people are religious, or at least believers. The overwhelming majority of the Brazilian population claims to believe in God, according to successive surveys conducted both by the Brazilian Institute of Geography and Statistics (IBGE, 2012) and other research institutes.

Brazil is said to be a multi-religious country and it is not surprising that, even among those who call themselves atheists, one hears the expression thanks to god, a striking feature of national culture.

It is interesting to mention a more specific feature of Brazilian religiosity, according to the statistical surveys of the 2010 Census, which is a manifestation of this pluralism in the same individual, that is, a considerable number of Brazilians who have declared multiple religiosity (or multiple belonging), which is to say that they are followers or faithful of two or more religious institutions (ORO, 2013, p. 77; 189).

However, it is unquestionable that religious intolerance is also very present in today's Brazilian society, not least because of the historical roots of these abusive practices, and because of the late and incomplete arsenal of measures to combat this form of intolerance.

Apart from this, it should be noted that religious intolerance can come from anywhere, that is, from state agents as well as from private individuals, who are mostly followers of other religions, or dissidents of the same tradition or religious denomination.

Gonçalves, referring to a historical example of religious intolerance in our country, comments that even Brazil, "a country without a tradition of religious conflicts, records the serious case of the Canudos War, marked by the religious intolerance of the State and of a religion against a spiritual leader (Antônio Conselheiro)" (GONÇALVES, 2013, p. 115). 
About religious intolerance, in the Brazilian context, the actions perpetrated by groups of criminals who somehow feel allied with certain religious leaders of some evangelical churches also impress, culminating in the destruction of temples and acts of violence against adherents of other religions, notably those of African origin ${ }^{4}$.

Cunha reports this scenario of religious intolerance:

Now it is the turn of a new modality, certainly more worrying: the alliance of the adepts of this religious current with drug traffickers, converging in an even stronger violence against umbanda, candomblé and other expressions of African origin (CUNHA, 2018, p. 256).

The issue of religious intolerance in Brazil was even portrayed by an important work of Brazilian dramaturgy, The Payer of Promises, by Dias Gomes, (first published in 1959) and whose narrative time pointed to the sixties of the last century.

In this literary narrative, the protagonist called Zé-do-Burro is the representation of the individual who, because of his religiosity, suffers from the conduct of intolerance, both by the followers of the dominant religion (in this case, Father Olavo, the Catholic priest and other faithful), and by the public authorities appearing there, who did not protect Zédo-Burro in his right to religious freedom and, on the contrary, took his life.

Zé-do-Burro and his religious perception, syncretic, mixed with elements of African religiosity, slave, poor, dominated in sociological and historical perspectives, represents the oppressed in the face of what would be the correct religion, hegemonic, tutored by the public power, although, formally, Brazil was a secular state at the time of the narrative.

Father Olavo's intolerance of the religiosity of Zé-do-Burro frustrates any attempt at inter-religious dialogue, because of the religious syncretism admitted by the Pagador de Promessas between the figure of Iansan, an orixá worshipped in Candomblé, here representative of the oppressed religiosity, and Saint Barbara, a saint venerated in Roman Catholicism, representing the institutionalized and dominant religion.

The process of demonization of African culture, and consequently of AfroBrazilian religions, is still evident in daily life in Brazil, so that dances, music, folklore and traditions are commonly understood as malign expressions. This discriminatory routine does not occur when references are made to Nordic, Celtic, Anglo-Saxon, and Greco-Roman religious traditions, praised as mythologies. Thus, Thor is the Nordic god of thunder and battles, admired by many as a worthy hero, while Ogun, the African orixá of

\footnotetext{
${ }^{4}$ The process of criminalization of popular uses defined as magic, charlatanism or sorcery is a phenomenon well known and researched in Brazil. Several studies reveals what and how, "in the name of defense of order and public health the state criminally persecuted mediums, "mothers and fathers of the saint," for "shamanism," and in the name of the "true religion" the Church denounced and fought "false religions," superstition and magic” (Giumbelli 1997; Schritzmeyer 2004; Montero 1985).
} 
war, iron, and crops, is considered a demon in the mindset of many Christians, especially certain more sectarian Pentecostal Protestants.

The same demonization takes place with Exu, an African orixá who is part of the pantheon of divinities worshipped in the Candomblé of Nagô tradition. It regulates sex, communication, controversy, renewal chaos, the movement. It is considered as the messenger between the material and the immaterial.

Prejudice and intolerance of Exu qualify him as the Devil, especially when he is visualized with a trident in his hands, one of the symbols attributed to this orixá, in Brazil. However, the trident in the hands of the Hindu god Shiva, the Roman god Neptune, or the Greek god Poseidon, does not cause such superstition and prejudice, nor does it place them as demons.

Not by chance, the Report on Intolerance and Religious Violence in Brazil (RIVIR), for the years 2011 to 2015, presented in 2018 by the then Ministry of Human Rights, registered attacks in eleven regions of the country against forty-five places of worship of African religions (BRAZIL, RIVIR, 2016).

In the state of Rio de Janeiro alone, in 2017, eight hundred cases of religious intolerance were registered, where most of the victims (71.5\%) are practitioners of African religions, with a daily average of two cases $(\mathrm{G} 1,2018)$.

The newspaper Estadão, in an article published in 2016, emphasized the increase of $3,606 \%$ in the number of accusations of religious intolerance in the last five years, according to data from the Ministry of Human Rights' survey at the time. According to the journalistic report, anthropologist Christina Vital, of the Sociology department of the Fluminense Federal University, drew attention to the increase in the number of African religions that have been invaded and burned (ESTADÃO, 2016).

However, religious intolerance does not only victimize followers of Afro-Brazilian religions such as Candomblé and Umbanda. The Report, mentioned above, also mentioned twenty-two cases of religious intolerance against symbols of the Roman Catholic faith between the years 2011 and 2015.

An example of this intolerance against Catholics, although prior to the period pointed out by the Report, but which became emblematic, was the kick in the saint, a controversial episode that occurred in October 1995, when a former bishop of the Universal Church of the Kingdom of God, Sergio Von Helder, insulted an image of Our Lady of Aparecida with words, punches and kicks during television programming.

The allegations for the religious offense committed by the ex-bishop were that veneration of images and Catholic saints would be forms of idolatry and, consequently, non-compliance with biblical ordinances. The insult generated great indignation among Catholics, who considered the fact to be unjustifiable conduct of religious intolerance, and which earned the bishop a criminal conviction for the crimes of religious discrimination and vilification of that symbol of the Catholic faith. 
Religious intolerance can also start from the very environment of belief and be aimed at individuals or groups of the same faith. This friendly fire occurs, for example, with discriminatory behaviors directed against certain classes of people, on the grounds of sex, marital status, purchasing power, schooling, sexual orientation, race, etc.

Thus, if in a religion the priesthood is not allowed to women, on the basis of dogmatic foundations, principles or values of this belief system, discussions may arise as to the boundary walls between the right to freedom of religion and religious intolerance, as well as the extent to which public power and the legal system could interfere in such matters.

Another expression of this "friendly fire" can be observed when a certain religious, considered less conservative in the customs and dogmas of his religion, comes to support some other religiosity considered an adversary.

In other words, at times the fight against religious intolerance can lead to more intolerance against the one who proposes measures of solidarity, respect, empathy and otherness in favour of the one who is different.

By way of illustration, this phenomenon was verified when the evangelical pastor and gospel singer Kleber Lucas, after having participated in a Candomblé event in Duque de Caxias/RJ on November 22, 2017, began to suffer attacks on social networks from certain other evangelical religious who called Kleber Lucas a possessed man (EXTRA, 2017).

It is interesting to note that this ecumenical event, although it took place inside a religious candomble temple, brought together representatives of the evangelicals and African religions, precisely to celebrate the donation of a sum of money, collected for the reconstruction of the "terreiro" (a term used in Candomblé) that was criminally burned in 2014 by radical and intolerant religious.

Sociological and anthropological studies show that the Brazilian people predominantly preserve a democratic-religious style, forged in an environment of high cultural diversity and leveraged by the syncretism of beliefs and the acceptance of ecumenical practices.

About this profile of Brazilian society, the anthropologist Da Matta ${ }^{5}$ writes:

The point is to consistently use the discovery that Brazilian society is relational. A system where the basic, the fundamental value, is to relate, to bring together, to confuse, to reconcile. To stay in the middle, to discover mediation and to establish gradation, to include (never exclude).

\footnotetext{
${ }^{5}$ An important aspect raised by the brazilian anthropologist Roberto Da Matta is that the Brazilian lives a dilemma constituted by the oscillation between two social units distinct: the individual - the subject of universal and egalitarian laws that modernize the society - and the person - the subject of the social relations that lead to the dimensions hierarchical systems. (DA MATTA, Roberto. Carnavais, malandros e heróis: para uma sociologia do dilema brasileiro. 6.ed. Rio de Janeiro: Rocco, 1997.)
} 
Synthesizing models and positions seems to constitute a central aspect of the dominant Brazilian ideology (DA MATTA, 1987, p. 117).

Despite this pluralism and such a relational profile, it is observed that the myth of the unequal yoke is also present in our society. This expression, which is most used among evangelicals, from a biblical verse ${ }^{6}$, puts into context a recommendation against dating and marriage between a confessed Christian and a non-Christian.

This manifestation of intolerance, in some religious circles, takes on the aspect of a true prohibition which, if breached, will even matter in the exclusion from the list of members of the local church.

It is paradoxical that the myth of the unequal yoke should apply precisely to love relationships - although this is not the focus of this essay, but proselytism, we only mention it as an example -, for all distinctions should lose meaning in the face of the supremacy of love and in the reasonable reasoning that an ecclesiastical rule should not be more relevant than the emotional achievements generated by the union between people who love one another.

Of the many other expressions of religious intolerance that could be added to this article, it is pertinent that the question of sexuality should not be overlooked, since it constitutes fertile ground for controversies that oppose, on the one hand, the idea of freedom with regard to sexual orientation and other related social behaviors, and on the other, more rigid and conservative religious principles.

Issues such as the acceptance by certain religions of the entry of homosexuals as members, the celebration of same gender religious marriages, and the very controversy of gay healing still yield vociferous discourses and claims on both sides, usually antagonizing the constitutional guarantee of the fight against discrimination and prejudice with the equally constitutional right to religious freedom, which includes proselytism and the apology of faith.

Thus, for example, if a (Catholic) priest, a (Protestant) pastor or any member of the Islamic community initiated into religion, charged with celebrating a marriage between persons of the same sex and same gender, refuses to minister in this celebration, a great forum is opened for debates on whether such a negative would be an ecclesiastical prerogative based on legitimate freedom of belief, or whether it would constitute an act of religious intolerance.

\section{Some Instruments for Reducing Religious Intolerance}

It is often seen that the lack of concreteness of a human right is precisely due to the gap between its mere formal consecration and the practical conducts that demonstrate the reality of the deficit of its effectiveness in social cuttings.

\footnotetext{
${ }^{6}$ This is verse 14 of chapter 6 of Paul's Second Letter to the Corinthians, which says: Do not be unequally yoked with unbelievers; for what society can there be between righteousness and iniquity? Or what communion, of light with darkness? (BÍBLIA, 1999, p. 1379).
} 
In this aspect, it can also be observed that there is no lack of texts and discourses of a moral and juridical order that establish the commitment to the question of religious tolerance. This is noted in international documents, in various national legal systems, as well as in the principles and values of numerous religions, whether institutionalized or not, ancient or more recent.

Moreover, love of neighbor is practically a maxim which is constant in most religions of the past and the present, and which is made perceptible in the respective holy books (for the religions which contain this element), in liturgical practices, in the professions of faith, by the guidelines and exhortations of religious leaders, and even through the commonly expected behavior of the followers of these same religions.

In the juridical field, there is the contribution of international law through various treaties and conventions with humanitarian content, such as the Universal Declaration of Human Rights (UDHR), approved by the General Assembly of the United Nations on 10 December 1948.

Fruit of the 1948 Declaration and more specific to the cause of combating religious intolerance, the Declaration on the Elimination of All Forms of Intolerance and Discrimination Based on Religion or Belief, proclaimed by the General Assembly of the United Nations on 25 November 1981 by Resolution No. 36/55 (UNITED NATIONS, 1981), deserves mention.

There are also other international regulations on the theme of religious freedom and the fight against conduct of intolerance to the worthy exercise of this right, such as the Declaration on the Rights of Persons Belonging to National, Ethnic, Religious and Linguistic Minorities, approved on 18 December 1992 by the General Assembly of the United Nations (UNITED NATIONS, 1992).

In terms of Brazilian national law, there is also a protective legal framework, both constitutional and infra-constitutional, such as Federal Law 11.635 of 27 December 2007, which symbolizes all these efforts by consecrating January 21 of each year as National Day for Combating Religious Intolerance.

From the inclusion of this date in the civic calendar of the country, including for official commemoration purposes, events such as the March to Combat Religious Intolerance began to take place in several Brazilian cities, gathering renowned religious leaders of different shades, with the aim of better projecting this theme to Brazilian society.

From the dogmatic point of view, several religions contemplate, by means of their principles and values, teachings and rules aimed at tolerance with the other, as well as the reproach for extreme conducts and disrespect for the cosmovision of others.

The ethics of reciprocity, spread by the main world religions, is a moral principle, which can be expressed both in the form of an ideal directive conduct (treating the other as you would like to be treated, the so-called golden rule) and a prohibitive injunction (not treating the other as you would not like to be treated, the so-called silver rule). 
It requires the development of attitudes of otherness and empathy and is present, in the form of the silver rule, in Zoroatrise, Buddhism, Confucianism, Hinduism, Judaism and Islam. In Christianity, the principle on canvas is announced by an affirmative proposition: whatever you want men to do to you, so do you also to them; for this is the Law the Prophets ${ }^{7}$.

The so-called Law of Cause and Effect, also known among the followers of Spiritism as the Law of Return, also suggests that undue actions practiced against someone will inevitably yield future spiritual harm.

Similarly, the Parable of the Sower ${ }^{8}$ teaches that good seeds planted will yield good fruit, in an allusion to the importance of good conduct so that, later on, this same sower may be rewarded with the result of his actions.

Intolerance, therefore, is not taught or encouraged, according to the moral and behavioral rules set out above, nor is it perceived that unbridled proselytism and vociferous discourse are tactics proposed by religions.

In the biblical text, as an example, humility, meekness, mercy, and pacification are the beatitudes ${ }^{9}$ taught by Jesus Christ to his disciples during the Sermon on the Mount, considered the great ethical pact for Christians.

Still in the Bible, there are guidelines for Christians that convincing people of the risks of sin is God's task ${ }^{10}$, and not man's. These instructions are sufficient to show that radical and aggressive conduct by certain individuals and groups against adherents of minority religions, such as those of African origin in our country, do not derive from Christian principles, but are deviations from the conduct of certain religious.

However, perhaps the greatest instrument for combating religious intolerance will be, in a theological and moral conception, precisely interreligious dialogue ${ }^{11}$, a probable antidote for ceasing or diminishing the disputes of space by religions, discouraging fundamentalist and violent conduct contrary to the belief of others, and adjusting the

\footnotetext{
${ }^{7}$ Text from verse 12 of Chapter 7 of the Gospel of Matthew (BÍBLIA, 1999, p. 1110).

${ }^{8}$ Teaching of Jesus Christ to his followers, described in the Gospels of Matthew (chapter 13, verses 1 to 9), of Mark (chapter 4, verses 3 to 9) and of Luke (chapter 8, verses 4 to 8).

${ }^{9}$ Verses 3, 5, 7 and 9 of Chapter 5 of the Gospel of Matthew (BÍBLIA, 1999, p. 1106).

10 "When he comes, he will convict the world of sin, of justice and of judgment". Text from verse 8 of Chapter 16 of the Gospel of John (BÍBLIA, 1999, p. 1259).

${ }^{11}$ To make this dialogue possible, we propose the use of diatopic hermeneutics. Diatopic hermeneutics was defended by Raimon Panikkar (2002) as a methodology for intercultural dialogue. To be guided by this methodology is much more than the mere application of an interpretation technique. Knowledge is important with the operationalization of conceptual distinctions, which sustain and legitimize it, such as concept / symbol, logos / mythos, alius / alter, multiculturalism / interculturality. The explanation and articulation of these conceptual pairs, among others, form the categorical framework presupposed by diatopic hermeneutics. There are several research groups that bring the issue of Human Rights closer to the so-called critical multiculturalism. Among these groups, Boaventura de Souza Santos is one of those that refer to diatopic hermeneutics and the concept of homeomorphic equivalents, proposed by Raimon Panikkar (2002).
} 
proselyte discourse to a dimension of persuasion, which preaches peace and solidarity among men, and not persecution, destruction and death.

On the importance of inter-religious dialogue, Pfeffer explains:

[...] Dialogue opens new perceptions of truth and the absolute in the different religious traditions and is therefore incompatible with every kind of fundamentalism which claims to possess absolute truths. On the level of doctrines, dialogue cannot go beyond confrontations where every believer hides himself; on the level of faith, dialogue enables believers to find themselves in their deepest convictions, in those which give meaning to their lives. Only faith, being a personal choice and not something that has been received to be transmitted, can be revised and enriched through dialogue with other people guided along a different path (PFEFFER, 2009, p. 30).

The fight against religious intolerance inevitably involves attempts and effective conduct aimed at promoting a respectful dialogue between the different, which applauds disparities, based on a universal ethic which values the human aspect of each being above any religious tradition or any philosophical conviction of its own.

Küng (2004, p. 17) goes so far as to affirm that "there will be no peace among nations unless there is peace among religions. There will be no peace between religions if there is no dialogue between religions. There will be no dialogue between religions unless there are global ethical standards".

A case worth highlighting in the analysis of inter-religious dialogue as a tool for combating intolerances on the grounds of religious beliefs is the hazy scenario that has formed contrary to Islam, especially in the West.

The fateful attacks of September 11, 2001 in the USA, in the minds of many, were enough to stigmatize all followers of Islam as terrorists, inaugurating a wave of discrimination, prejudice and intolerance against Muslims.

Although fundamentalist Muslims see $J_{i h a d^{12}}$ as a sufficient foundation not only to defend the Islamic faith, but also to promote terrorist attacks, such as blowing up aircraft in buildings or beheading enemies considered unfaithful, this interpretation cannot be said to be defended by all Muslims, least of all by Islam.

\footnotetext{
${ }^{12} \mathrm{Jihad}$ is an Arabic word meaning "conflict" or "competition", indicating some religious war of the Muslims against the unbelievers, that is, members of other religions (CHAMPLIN, v. 3, 2008a, p. 510). This concept exemplifies a concept better known and current in the West, notably derogatory and incomplete about the deeper meaning of Jihad, a conclusion arrived at when one observes the breadth of the foundations, principles and values of Islam, which are reduced to the idea that Muslims use this "holy war" as an instrument of intolerance, persecution and violence against those who do not follow the Islamic faith. (IQARAISLAM. O que é Jihad ou Guerra Santa? Accessed on: 28 Jan. 2021. https://iqaraislam.com/o-que-e-jihad-ou-guerrasanta).
} 
One of the ways found to minimize the negative effects of this intolerance of Islam, after the aforementioned terrorist attacks and the absurd actions of the Islamic State, was precisely the initiative of various religious denominations, especially the Catholic Church, to promote numerous meetings and events within and outside their institutional networks, such as the Commission for Ecumenism and Interreligious Dialogue and the House of Reconciliation, in order to bring together religious leaders to discuss various ideas and projects aimed at stimulating fraternity among peoples and their beliefs (HAMMADEH, 2018, p. 37).

As for the expected behavior of the Brazilian public power, with regard to the fight against acts of religious intolerance, it must be emphasized that such a mission must integrate the political agenda of all federal entities, through affirmative actions and public policies in the short, medium and long term, duly organized, through social propositions and needs.

One such measure is the creation of specialized police stations for the prevention and repression of crimes and conduct in general of religious intolerance, which has already taken place in the Federal District, São Paulo, Rio de Janeiro, Mato Grosso do Sul, Rio Grande do Sul and other federal units in Brazil.

The reporting channel established by Dial 100, maintained by the federal government through the current Ministry of Women, Family and Human Rights, also serves as an important tool for collecting reports of religious intolerance in our country.

The creation and maintenance of specialized services in the structure of the Public Prosecutor's Offices and Public Defender's Offices also tend to offer respectable support in this endeavor of reprimanding deviations from the correct exercise of religiosity. An example of this is the Commission to Combat Religious Intolerance of the Public Prosecution Service of the State of Rio de Janeiro.

However, there are a number of other suggestions for government action that can be implemented, such as the creation of Mediation Chambers specializing in the area of religious freedom; the training of public servants and managers assigned to deal with this area; the institution of reparatory actions to ensure that victims receive compensation for damages suffered and the possible reconstruction of destroyed temples; the creation of councils for the defense and promotion of religious freedom; the training of teachers, pedagogical advisors and school headmasters on the principles of secularity and religious freedom, among others.

It is noticeable that Brazil has not reached levels of persecution comparable to those of countries where certain social groups, nourished by feelings of xenophobia, racial hatred, homophobia, religious warfare, anti-Semitism, anti-Arabism and other distortions, reach the point of organizing actions of extreme violence and cruelty. But there is also no reason to run the risk of paying to see intolerance become a characteristic mark of our society. This progression must be stopped.

And of all that can be thought or done, the most likely effective instrument against religious intolerance is the awareness of each individual, even if one sees in it something 
utopian or philosophical. Suffocating the seed of the poisonous tree, or even allowing it to be deposited in the ground, are the most prudent ways of preventing the poisonous fruits of that tree from being consumed in the future.

It is noticeable that Brazil has not reached levels of persecution comparable to those of countries where certain social groups, nourished by feelings of xenophobia, racial hatred, homophobia, religious warfare, anti-Semitism, anti-Arabism and other distortions, reach the point of organizing actions of extreme violence and cruelty. But there is also no reason to run the risk of paying to see intolerance become a characteristic mark of our society. This progression must be stopped.

And of all that can be thought or done, the most likely effective instrument against religious intolerance is the awareness of each individual, even if one sees in it something utopian or philosophical. Suffocating the seed of the poisonous tree, or even allowing it to be deposited in the ground, are the most prudent ways of preventing the poisonous fruits of that tree from being consumed in the future.

On the relationship between otherness and (in) tolerance, Cerqueira Filho make the following considerations:

[...] the practice of alterity, from the earliest age, coupled with the diversity of the Other, contributes powerfully to the practice of tolerance: on the other hand, by replacing the practice of alterity and diversity, from the earliest age, by isolation and the self-referential image of oneself, we create the conditions for the social practice of intolerance. (CERQUEIRA FILHO, 2015, p. 422).

While intolerance is the certainty of possessing an absolute truth, otherness is the wisdom of understanding that such truth can and should be regarded as relative, not out of hypocrisy, cowardice, uncertainties, or shady pacts with some lie, but out of respect for the conviction and expression of the other, after all, better than always being right is to have peace with oneself and to promote solidarity among men.

In any case, it is important to point out that the concept of tolerance arises in the liberal tradition which sought to separate the powers of the State with the powers of the Church, which were in constant political dispute at the time of the formation of modern national States, as well as to guarantee the freedom of expression of thought and autonomous action of individuals, so defended by Locke in his classic liberalism. Such a concept can be associated with the quest then undertaken to create a neutral public space guided and regulated by rationalism and scientificism, breaking with the tradition and religion dominant in its historical period (WALDRUN, 2009).

This vision of tolerance is consolidated with the rise and hegemony of liberal thinking, and is configured as a culture of tolerance, or even a tradition of tolerance; thus, it is possible to consider the existence of a historical relationship between the origin of the modern liberal state and the birth of tolerance in a political sense. 
This traditional culture of tolerance, however, presents a major problem for contemporary societies. The expected neutrality does not, strictly speaking, show itself to be a possibility of diverse manifestations, individual and/or collective, without arbitrariness in a common and socially shared space. This can be seen in a society and a State indifferent to the particularities of the different cultures and individualities that pass through the public space. The disproportionalities and inequalities between the different social groups within the same social environment remain, illusorily, protected by the neutrality of the state.

Liberal ideology, characterized by public-private division, guarantees individual freedoms only in the private sphere, maintaining the structure of domination and cultural hegemony in those societies and states in the public space; this clear difference between tolerance and tolerant attitude is revealed, that is, tolerance appears as indifference towards the other and his individuality, tolerating him, instead of recognizing him as different from himself and yet bearing the same social, political and legal rights and guarantees, understand, accepting him as such.

The tolerance of the liberal state, paradoxically intolerant, less accepts and admits cultural, ethnic, social, religious and gender differences and diversity than it announces; on the contrary, it establishes legitimate ways of perpetuating intolerance in the public sphere, believing itself to be neutral, rational, out of context, free from historical, political, social and cultural conditioning. It ends up neglecting differences in the public sphere, and thus legitimizes intolerant actions on the part of members and organizations of dominant cultures. In other words, indifference is translated into neutrality.

It is therefore urgent and necessary to review the concept of tolerance today. Despite its transformations, the modern State, instead of stimulating peaceful coexistence, promotes and instrumentalizes intolerance and indifference towards otherness. From this perspective, it is necessary to make use of the pretension of a universality that is inclusive, together with the idea of an objective rationality with a liberal profile, and to seek understandings close to the conceptions proper to each culture.

There are not enough universal parameters to contemplate peace and tolerance among different individuals. It is necessary, as Walzer (1999) argues, to build solutions based on the history and culture of each social group, instead of trying to impose a specific form, supposedly neutral and rational, disregarding the context in which each group finds itself.

The impossibility of adopting universal standards and formats to solve multi-ethnic, multicultural problems requires a new culture of tolerance, desired by Walzer (1999). It cannot renounce relativism in the face of institutions and political regimes, as well as of the dominant culture itself, so that there can be a dialogue between this fragmented social world. Without the imposition of a totalitarian, maximalist political model, which underestimates the diversity and differences inscribed in every social space.

Not only is relativism fundamental to the new culture of tolerance; the recognition of otherness, of the identity of the other, is crucial to promote understanding and peaceful 
coexistence between different social, ethnic and religious groups. Individual identity is only really built when in confrontation with difference; the recognition of one's own identity is only possible through the recognition of one's own diverse and different identity, providing a self-discovery of one's own individual together with the other.

The other behaves less as an enemy than as the mirror by which the "self" can recognize itself from the similarities and dissimilarities, styles and spaces that take place through the recognition of "himself" in the other. From the contrast with the other, the "self" can distinguish its partialities so that without the other, without the dissimilar, the diverse, it is impossible for the "self" to recognize itself in all its aspects - cultural, social, gender, religious - so that intolerance denotes an experience of non-recognition, since the other is barred from participating in the sphere of the public and the common.

Recognition and relativism, conformed in the perspective of overwhelming the old idea of tolerance, may give a new and more efficient form of association between individuals belonging to different cultures; individuation can only be completed by opposing a different one, and, on the other hand, that no conception of good life is complete and fully pleasing, always needing to be opposed with other visions (WALZER, 1999).

This whole new culture of tolerance, which can be constituted from another epistemological point of view, is substantially closer to Ubuntu - "I am because we are". The understanding, achieved by this thinking of African roots, that the "I" only exists in harmony with another, and that a human being is a human being from the relationships he hints out with another human being, leads to the creation of conceptual tools and the implementation of current practices to identify/comprehend otherness; changing intolerance with a harmonious and fruitful relationship between different individuals. The "self" is only constructed, established, and identified in relation to the other, so that the other becomes a partner of the "I" rather than an adversary.

Therefore, some reflections on religious intolerance refer to observations of extreme negation of otherness, and even of flagrant paradoxes, such as imagining that the function of reconnecting the immanent to the transcendent, distorted by hatred, prejudice, and violence, entails exactly the opposite of this objective, which is to disconnect the individual from his fellow man and from divinity, breaking up horizontal and vertical relations.

Other contradictions that religious intolerance produces, in denying otherness, is to use belief to deny some belief, to preach the eternal, worrying more about the immediate, to be guided by the proselytism of a belief, to abuse the right to freedom of religion.

Hogemann, speaking about the Ubuntu philosophy, praises the importance of otherness:

The self always places itself in need of another, both for the self and for the other since one cannot be self without being another. The otherness 
of others helps people to recognise their own uniqueness, their role, importance, duties and need. The otherness of others includes the diversity of languages, histories, values and customs, everything that constitutes human society (HOGEMANN, 2017, p. 115-116).

Alterity, in terms of religiosity, is made impossible when the other and his or her belief are subjugated, interiorized, or invisible in their identity and power, and is related to the concept of interculturality, which seeks a balance of perspectives, so that religions can live together in solidarity and mutuality, in openness to the other and through harmonious and respectful communication, projecting experiences of plurality (RIBEIRO, 2016, p. 51).

Reality shows how far humanity must go to experience days of tolerance, not only in the field of religiosity, but in so many other areas of complex human coexistence.

But one step at a time must be taken, or as the Bible says, each day its own evil is enough ${ }^{13}$. What can no longer be admitted is that religious intolerance continues to stain the human journey through the centuries and defy the pillars of human rights.

\section{CONCLUDING REMARKS}

At the end of this essay, it is concluded that religious intolerance is a serious deviation from the legitimate exercise of the human right to religious freedom, and that it has served as a nourishment for other forms of prejudice, discrimination, persecution, and even armed war.

It has been seen that, in many cases, such conduct of intolerance is a distortion of the essence of the humanitarian right of religious freedom, and that it takes advantage of the proselytism of belief and the defense of faith, which are authorized expressions by law and morally acceptable.

In this sense, intolerance ends up being a repellent attitude to religion, because it discourages many from approaching any religiosity, because of the risks of experiencing or even becoming victims of sectarianism and fundamentalist attitudes.

The religiosity of minorities tends to be a more susceptible target of acts of intolerance, as is the case, for example, with African religions, still today in Brazil, when adherents and temples of Candomblé and Umbanda suffer attacks from certain radical religious.

It is observed that Brazil, predominantly, remains a country of tolerance in the field of religions, through initiatives of inter-religious dialogues, ecumenical practices and syncretic varieties.

\footnotetext{
${ }^{13}$ Text from verse 34 of chapter 6 of the Gospel of Matthew (BÍBLIA, 1999, p. 1109).
} 
However, statistics and repeated reports of cases of religious intolerance show that the concern must cease to be theoretical and convolve into practical behavior, both by the public authorities, through affirmative action and public policies, and by civil society in general, based on processes of awareness and dissemination of habits of otherness.

Only with effective action can religious intolerance cease to be reported in our country, and true religious freedom will appear as a human right endowed with full social effectiveness, from which no one can claim to have any reservations.

\section{ReFERENCES}

BÍBLIA. Geneva Study Bible (1999). Tradução de João Ferreira de Almeida. 2. ed. São Paulo: Cultura Cristã; Barueri: Sociedade Bíblica do Brasil.

BRASIL. SUPREMO TRIBUNAL FEDERAL. Habeas Corpus 82.424-2 / RS. Paciente: Siegried Ellwanger. Impetrantes: Werner Canatalício, João Becker e outros. Coator: Superior Tribunal de Justiça. Relator: Ministro Maurício Corrêa. Data dojulgamento: 17 de setembro de 2003. Acesso em 20 de janeiro de 2021: http://portal.stf.jus.br/ jurisprudencia/verPdfPaginado.asp?id $=79052 \&$ tipo $=A C \& d e s c r i c a o=I n t e i r o \% 20$ Teor $\% 20 H C \% 20 / \% 2082424$.

CERQUEIRA F., G. Alteridade e (in) tolerância. In: NEDER, G .; SILVA, A. P. B. R. da; SOUSA, J. J. V. de (eds.) 2015. Intolerância e cidadania: secularização, poder e cultura política. Rio de Janeiro: Autografia.

CHAMPLIN, R. N. 2008a. Enciclopédia da Bíblia, teologia e filosofia. v.3. 9. ed. São Paulo: Hagnos.

CHAMPLIN, R. N. 2008b. Enciclopédia da Bíblia, teologia e filosofia. v.5. 9. ed. São Paulo: Hagnos.

CONCÍLIO ECUMÊNICO DE TRENTO (1545-1563). Acesso em 25 fev. 2005. http:// www.montfort.org.br/bra/documentos/concilios/trento/.

CUNHA, Luiz Antonio. 2018. Panorama de conflitos recentes envolvendo a laicidade do Estado no Brasil. In: Embates em torno do estado laico. São Paulo: SBPC.

DA MATTA, R. 1987. A Casa e a Rua: Espaço, Cidadania, Mulher e Morte no Brasil. Rio de Janeiro: Guanabara.

DIOP C. A. 2014. A Unidade Cultural da África Negra: esferas do patriarcado e do matriarcado na antiguidade clássica. Angola: Pedago.

DUSSEL, E. 1993. O encobrimento do outro: a origem do mito da modernidade. Tradução de Jaime A. Clasen. Petrópolis: Vozes.

ESTADÃO, 2016. As denúncias de intolerância religiosa aumentaram 3.606\% nos últimos 5 anos.Acessadoem26jan.2021.https://brasil.estadao.com.br/noticias/geral,denuncias -de-intolerancia-religiosa-crescem-3606-nos-ultimos-5-anos, 10000086766. 
EXTRA. Notícia. Rio. O cantor gospel Kleber Lucas é chamado de 'endemoniado' após evento no terreiro. 04 dez. 2017. Acesso em 26 jan. 2021.https://extra.globo.com/ noticias/rio/cantor-gospel-kleber-lucas-chamado-de-endemoniado-apos-evento -em-terreiro-22147168.html.

GIUMBELLI, E. 1997. O cuidado dos mortos: Uma história da condenação e legitimação do Espiritismo. Rio de Janeiro: Arquivo Nacional.

GOMES, D. 2002. The Payer of Promises. 36 ed. Rio de Janeiro: Ediouro.

GONÇALVES, A. B. 2013. Da intolerância religiosa aos Direitos Humanos. Acessado em 20 jan 2021 https://revistas.pucsp.br/index.php/ultimoandar/article/view/13986.

G1. RIO DE JANEIRO. 2018. O Rio de Janeiro registrou 800 serviços de intolerância religiosa em 2017, de acordo com a Secretaria de Estado dos Direitos Humanos. Acesso em 26 jan. 2021. https://g1.globo.com/rj/rio-de-janeiro/noticia/rj-registra -800-atendimentos-de-intolerancia-religiosa-em-2017.ghtml.

HAMMADEH, S.J.H. The Importance of Interreligious Dialogue in Islam. In: BIZON, C.J .; SCHLESINGER, R.M. (eds.); MOREIRA J.A. (idealiz.). 2018. Diálogo inter-religioso: Religiões no caminho para a paz. São Paulo: Paulinos.

HOGEMANN, E. R. 2017. Direitos humanos e filosofia do Ubuntu. Rio de Janeiro: Lumen Juris.

IBGE. 2012. Censo 2010. Rio de Janeiro: IBGE. Acesso. 22 de janeiro de 2021.https:// censo2010.ibge.gov.br/noticias-censo.html? View = noticia \& id $=3 \&$ idnoticia $=2170 \&$ busca $=1 \& \mathrm{t}=$ censo- $\%$ 202010-numero-catolicos-cai-aumenta -evangelicos-espiritas- sem-religiao.

IQARAISLAM. O que é Jihad ou Guerra Santa? Acesso em 28 de janeiro de 2021: https:// iqaraislam.com/o-que-e-jihad-ou-guerra-santa.

KÜNG, H. 2004. Religiões do mundo: em busca de um terreno comum. Campinas: Verus.

LOCKE, J. 1978. Letter on tolerance. In: The Thinkers. Translation of Anoar Aiex. Rio de Janeiro: Abril Cultural, p. 3-39.

MBEMBE, A. 2018. Critique of Black Reason. Translation by Sebastião Nascimento. Paris: $n-1$ editions. https://doi.org/10.2307/j.ctv125jgv8

MICHAUD, Y. 1991. Locke. Tradução: Lucy Magalhães. Rio de Janeiro: Jorge Zahar.

MONTERO, P. 1985. Da doença à desordem. Rio de Janeiro: Graal.

MONTERO, P. 2017. The "culture of justification" in the production of public religiosities in Brazil. In Mapril, Blanes, Giumbelli \& Wilson (eds.), Secularisms in a Postsecular Age?: Religiosities and Subjectivities in Comparative Perspective. Palgrave MacMillan. https://doi.org/10.1007/978-3-319-43726-2_10

NASCIMENTO, A. 2016. O Genocídio do Negro Brasileiro. Processo de um racismo mascarado. São Paulo: Perspectiva. 
ORGANIZATION OF THE UNITED NATIONS. United Nations General Assembly. Declaration on the Elimination of All Forms of Intolerance and Discrimination Based on Religion or Belief. 25 Nov. 1981. Accessed, 28 Jan. 2021 https:// www.oas.org/dil/port/1981Declara\%C3\%A7\%C3\%A3o\%20sobre\%20a $\% 20$ Elimina $\%$ C3\%A7\%C3\%A3o\%20de\%20Todas\%20as\%20Formas\%20 de $\% 20$ Intoler\%C3\%A2ncia\%20e\%20Discrimina $\%$ C3\%A7\%C3\%A3o\%20 Baseadas\%20em\%20Religi\%C3\%A3o\%20ou\%20Cren\%C3\%A7a.pdf.

ORGANIZATION OF THE UNITED NATIONS. United Nations General Assembly. Declaration on the Rights of Persons Belonging to National or Ethnic, Religious and Linguistic Minorities. 18 Dec. 1992. Accessed, 28 Jan. 2021 https://www.oas.org/ dil/port/1992\%20Declara\%C3\%A7\%C3\%A3o\%20sobre\%20os\%20Direitos\%20 das\%20Pessoas\%20Pertencentes\%20a\%20Minorias\%20Nacionais\%20ou $\% 20 \%$ C3\%89tnicas,\%20Religiosas\%20e\%20Lingu\%C3\%ADsticas.pdf.

ORO, I. P. 2013. O fenômeno religioso: como compreender. São Paulo: Paulinas.

PANIKKAR, R. 2002. Pace e interculturalità: una reflessione filosófica. Milano: Jaca Book, Accessed, 20 jul 2021 https:/www.famigliafideus.com/wp-content/ uploads/2016/08/PACE-E-INTERCULTURALITA-R.Panikkar.pdf.

PFEFFER, R. S. Diálogo inter-religioso e a construção da cidadania em um mundo globalizado: a contribuição do sincretismoreligioso. Revista Mosaic. Belo Horizonte -MG, v.1, n. 2, pág. 25-38, 2009. Acesso em 22 jan. 2021. http://bibliotecadigital.fgv .br/ojs/index.php/mosaico/article/view/62783. https://doi.org/10.12660/rm.v1n2 .2009 .62783

RIBEIRO, C. de O. 2014. Pluralismo e libertação. São Paulo: Paulinas.

RIBEIRO, C. de O. 2016. Religião, democracia e direitos humanos: uma presença interreligiosa pública no fortalecimento da democracia e na defesa dos direitos humanos no Brasil. São Paulo: Editora Reflexão.

RIVIR, Relatório sobre intolerância e violência religiosa no Brasil(2011-2015): resultados preliminares/Ministério das Mulheres, da Igualdade Racial, da Juventude e dos Direitos Humanos; organização, Alexandre Brasil Fonseca, Clara Jane Adad. Brasília: Secretaria Especial de Direitos Humanos, SDH/PR,2016. 146 p. Acesso em 24 jul 2021. http://www.mdh.gov.br/informacao-ao-cidadao/participacaosocial/ cnrdr/pdfs/relatorio-de-intolerancia-e-violencia-religiosa-rivir-2015/view.

SANTOS. I. dos. 2019. A Caminhada em Defesa da Liberdade Religiosa e seus desafios para a construção do diálogo inter-religioso. In: Numen: revista de estudos e pesquisa da religião, Juiz de Fora, v. 22, n. 1, jan./jun. 2019, p. 26-42.

SCHRITZMEYER, A. L. P. 2004. Sortilégio de saberes: Curandeiros e juízes nos tribunais brasileiros (1900-1990). São Paulo: IBCCRIM.

SLENES, R. W. 1992. "Malungu, ngoma vem!": África coberta e descoberta do Brasil. Revista USP, 12, 48-67. https://doi.org/10.11606/issn.2316-9036.v0i12 p48-67 
WALDRUN, J. 2009. Locke: Toleration and the Rationality of Persecution. Em: Mendus, S. (ed). Justificando a tolerância: perspectivas conceituais e históricas. Cambridge University Press. Pp. 61-86. https://doi.org/10.1017/CBO9780511735295.005

WALZER, M. 1999. On Toleration. Traduzido por A. Piseta. São Paulo: Martins Fontes.

WINNIFRED F. S. 2014. The Impossibility of Religious Freedom. Accessed em 22 jul. 2021 https://tif.ssrc.org/2014/07/08/impossibility-of-religious-freedom/

ZANONE, V. Laicismo. In: BOBBIO, Norberto; MATTEUCCI, N .; PASQUINO, G. 1986. Dicionário de Política. Brasília: UNB.

Received: February $6^{\text {th }} 2021$

Accepted: August $2^{\text {nd }} 2021$ 